\title{
Malay Dance: Expression on Maritime Society
}

\author{
Rina Martiara ${ }^{1}$ \\ Jurusan Tari, Fakultas Seni Pertunjukan, Institut Seni Indonesia Yogyakarta
}

jurnal tari, teater, dan wayang volume 1 number, 1 May 2018 page $50-58$

\begin{abstract}
Nusantara as bhinneka (unity) culture has not been studied completely and comprehensively. It is only called as equatorial emerald region that most of the people are farmer. Children's song says that my grandmother is a sailor, but Nusantara's society can not precisely express the distance of society with the ocean. The current dance research examines dance as a particularistic study of dance on a particular tribe, and it ignores the extensive research on a large scale. This study will evolve to find the cultural mapping of Nusantara dance based on cultural style categorization of mental map; it is a new awareness of how to think based on cultural geography. The approach of the study was the analysis of the motion structure that builds a dance and all the supporting aspects that will create the cultural style of the community. Textual analysis will examine the elements of dance those are motion, accompaniment, floor pattern, property, makeup and clothing, outfit of show. Contextual analysis was used to analyze the cultural values in the dance. Those two methods can be used to draw aesthetic patterns possessed by Malay culture. The conclusion of maritime culture pattern study presented that there were four different patterns with farmer community pattern which have three patterns and rice farmer which have five patterns.
\end{abstract}

Keywords: Malay dance; maritime culture; pattern of four

\begin{abstract}
Abstrak
Tari Melayu: Ekspresi Masyarakat Maritim. Nusantara sebagai budaya yang bhinneka selama ini belum mendapat kajian secara tuntas dan komprehensif. Nusantara hanya disebut sebagai daerah zamrud khatulistiwa yang sebagian besar masyarakatnya adalah petani. Lagu anak-anak mengatakan bahwa nenek moyangku seorang pelaut, tetapi justru masyarakat Nusantara tidak mampu menyatakan secara jelas jarak masyarakat dengan lautan. Penelitian tari yang berkembang sekarang ini umumnya lebih banyak melihat tari sebagai studi yang partikularistik mengenai tari pada suatu suku bangsa tertentu, dan melupakan kajian yang meluas dalam skala besar. Kajian ini akan berkembang untuk menemukan pemetaan budaya tari Nusantara berdasarkan kategorisasi gaya budaya yang didasarkan pada mental map, yaitu satu kesadaran baru tentang cara berpikir berdasarkan geografi budaya. Pendekatan yang digunakan adalah analisis struktur gerak yang membangun sebuah tari dan seluruh aspek pendukungnya yang akan membentuk gaya budaya masyarakat tersebut. Analisis tekstual akan mengkaji unsur-unsur tari yang terdiri dari: gerak, iringan, pola lantai, properti, rias dan busana, perlengkapan pertunjukan. Analisis kontekstual digunakan untuk menganalisis nilai-nilai budaya yang terkandung di dalam tari tersebut. Dari kedua metode tersebut dapat dipetakan pola estetis yang dimiliki oleh budaya Melayu. Simpulan yang dapat ditarik
\end{abstract}

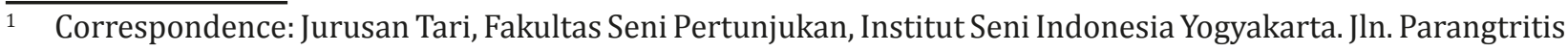
KM 6,5 Sewon, Yogyakarta. E-mail: martiararina@yahoo.com. HP.: +628121213366. 
bahwa pola budaya maritim adalah pola empat yang berbeda dengan pola masyarakat petani ladang yang berpola tiga dan petani sawah yang berpola lima.

Kata kunci: tari Melayu; budaya maritim; pola empat

\section{Introduction}

This study analyzed and mapped Malay dance in the mapping of Nusantara dance culture based on cultural style categorization of mental map. It is a new awareness of way of thinking based on cultural geography. Those mental base of the map becomes the substance to understand the culture complexity in Indonesia. The differences of mental map do not only create diversity of ethnic and geographical; but it also shows different points of view in many aspects, demonstrates the enactment of different value system between groups, and affirms the existence of different social, economic, and political behavior with each other. Based on those explanations, each pattern of transformation builds up within the mental map of the community itself, and the resulting pattern will give the cultural identity aspect that will find the human mind of the supporting community.

The concepts used in categorizing the Nusantara dance style are based on the opinion of Onghokham and Kuntowijoyo. As a result, it can be summarized that Indonesian society is not only divided into maritime and agrarian communities. The maritime community is turned into a maritime society that only relied on marine life, and maritime communities which lives on the coast and relies on their livelihoods from farming. The Nusantara agrarian culture is also distinguished into wet rice cultivation shifting cultivation (Geertz, 1971:12-37 and Nasikun, 1984:44). Based on the pattern system of culture, pattern of two is an expression of the concord culture; pattern of three is the primordial culture of the field; pattern of four is the maritime culture; and pattern of five is the culture of the wetland farmers. The Indonesian cultural patterns are generally the expressions of maritimefarm culture which are also found in coastal and cultivated coastal areas that develop themselves in shipping and trade activities, such as those in Sumatera (Malay), Sunda, Java, Bugis, Makassar, and Aceh (Sumardjo, 2006: 28). These ecological problems are also biased in the different systems of government, as stated by Soewarno (1997) that there were three systems of government in Nusantara, namely the Malay system of administration (maritime) with the consensus system; Bugis (coastal-farm) with the house of people's representatives system; Java (inland, agrarian, rice field) with the royal system of government.

\section{History of Malay: History of Modest Traveler}

Malay is one of the tribes in Indonesia which inhabits almost the entire Nusantara area, they even extends to the Southeast Asia region. The characteristics that distinguish Malays from other people, especially in the past, are marine-oriented life patterns, Islamic religion as the main guideline of their lives, and relaxation in its social structures. Because their lives are marine-oriented, most of Malay's community grows on the seashore or large rivers that can be passed and overrun by large ships. This community usually becomes the center of international trades, trade expeditions, and shipping centers. If they are compared to an agrarian-oriented empire in the interior, the concept of legitimate offspring is more important in maritime-oriented societies, due to the agrarian kingdom, the king's legitimacy is more on the basis of the droplet concept (Ham, 1986: 183).

Geetrz (1963) said that Malay culture was classified as an urban-patterned coastal culture, and the center of the activities were trade and maritime. Malay culture used to connect with the outside world, so there was a cultural renewal process and acculturation 
which caused the Malay culture have had loose and open structures. The flexibility of the Malay cultural structure also applies in the structure of Malay language which is often called lingua franca. It is the intermediary language for commerce, and it accommodates communication barriers due to the differences in the system of meaning and language.

Goenawan (2008) said that Malay was not the identity of an ethnic group, but it was an elite layer which still associated with the king's blood. The book of Sejarah Melayu is practically the genealogy of the sultans. However, after Malacca felt into the hands of the Portuguese in 1511, the royal family fled to Johor, thus no longer a hegemonic holder that defined the meaning of "melayu". That word eventually spread alongside the diaspora of the merchants after Malacca's success. Malay is no longer an identity that shows a social layer, but it presents a horizontal identity. This name became marker in social grouping which was different but equal, especially in European's view of colonial power. Amir Hamzah, one of Indonesia's litterateurs, saw himself as part of a generation who wanted a change in the future. They wanted to escape from colonialism, a colonized, backward, and humiliated condition, something that was no longer called “Java, Malay, Ambon". Hamzah's view can be regarded as a post-Malay phenomenon, a period that can no longer be called "Malay".

Since 1930s, Indonesian poetry has been the poetry of "witched traveler", poets of explorers who had nothing but freedom to roam. Indonesia was born from that exploration. That is why Indonesian nationalism is not a nationalism that lifts up the property inherited past, both in the form of temples and biological provisions. It may become the reason of essential feeling of Indonesian concept and Indonesianised, but it has a meaning that is not easily underestimated. Do not accept to be called as "Indon", but call it as "Indonesia" because the name of "Indonesia" is a name that has been fought with no fuss since the beginning of the $20^{\text {th }}$ century.

\section{Maritime Century Southeast Asia $16^{\text {th }}$ and $17^{\text {th }}$ Centuries}

Southeast Asia (including Indonesia) which is now often used for agricultural research is actually dominated by maritime sultanate in the 16th century. The agrarian sultanate inland with peasant people are only a few, such as Mataram in Central Java, Ayuthia in Thailand, and Pagan in Burma. Meanwhile, the other centers of power are maritime kingdom, such as the kingdoms on the north coast of Java (Banten, Demak, Kudus, Surabaya, Pamekasan, and Sumenep), the kingdoms in Aceh, Siak, Indragiri, Pagarruyung (Sumatera), and the kingdoms of Makassar, Goa, Bone (Sulawesi), Ternate, Tidore or the Malacca Peninsula (Ham, 1986: 182).

The structure of the maritime kingdom is its inhabitants which are not peasants but seafarers and fishermen or craftsmen, as well as urban residents. Research which conducted showed that Sumatra and Malacca Peninsula did not do agriculture. The same evidence proved by Reid (1979) over Banten, Tuban, Gersik, and other areas on the north coast of Java. It was the Dutch and English who implanted or imposed the agricultural tradition. Initially, Malays had an agricultural tradition that produced export commodities, such as pepper, nutmeg, areca nut, and gracinia atroviridis. In addition, they grow rice and crops for daily use. From agricultural produce, they can live prosperously. After Malays' land became plantations, there were changes which did not only concern the economic system of the Malays, but also on the interests of the Sultan.

The Dutch government compensated to Sultan for damages, while the people were provided the land of strips that could be used for planting, but for seasonal crops, such as rice, corn, and secondary crop. Thus, the export agricultural tradition of Malaysian turns into subsystem agriculture. This change has given a psychological impact on Malay people. They are not used to clearing new forests and cultivating them into pepper or nutmeg farms. They only wait for the 
cultivated land, so they become the waiters, waiting until the harvest season of tobacco is finished, then they divide the land and plant rice or secondary crop. The change in the agricultural system was considered as the root of the Malay impoverishment process; and it implanted a relaxed lifestyle and depended on others (Pelly, 1986: 295).

After the capital entry and foreign plantation of tobacco in East Sumatra, the Netherlands praised prosperity "Cultuurgebied" as het dollarland; and they were endlessly degrading the Malays who have land. They pouted the laziness of Malays who did not want to work on the Dutch plantation. The activities which were done by the Malays was only marry, rejoice, pilgrimage, and then live with laziness. (Westerman). Their vast land was leased to Chinese and Javanese for vegetable, rice, or coconut planting (Plas, 1917). For example, the Malay expertise in silver carving in Batubara has vanished. It was similar to wood carving and others (Kempen, 1928: 393). Thus, it was mentioned by the Dutch that Malays made it possible for the Chinese and other immigrant tribes to take over the handicrafts and economic life in East Sumatra. It was mentioned by the Dutch East Indies government that the Malays would no longer be pressured by the Javanese in Asahan and by Tapanuli people in Labuhan Batu (Geristsen, 1938: 71-72). The official Dutch report concluded that the Malays residence provided an underdeveloped state and little economic progress, and also in the Cultuurgebied region of East Sumatra. The Malay people have not increased their progress with the arrival of European plantation systems in their country. They just pushed back (Erde, DLI: 248-254). However, it was recognized by them that the Malays were not rice field workers, because they were hunters and fishermen, and merchants (Kempen, 1928: 190).

\section{Pattern of Four in Structure of Malay Society}

According to Suwardi (1986: 211), the kingdom unity in Riau was started by the rule of the Little King (1717) which laid the foundations of unity in various aspects of life, such as government, territory, and cultural elements. However, subsequent division occurred, namely the Sultanate of Siak Sri Indrapura and Riau Lingga (1722). The changes had an impact on the political, social, and cultural aspects, and led to reforms in the Riau Malay Sultanate. The unity of the sovereignty and territory of the Malay Sultanate began to be split since the centralized government of the Small King in Buantan Siak Sri Indrapura and since the reign of Sultan Sulaiman Badrul Alamsyah in Riau-Johor in $1722 \mathrm{M}$.

The Sultanate of Siak was ruled by the sultan as the ultimate leader of the leadership and was accompanied by a royal council. The council of the kingdom consisted of large people who functioned as government executives and sultan's chief adviser.

They were four Datuk, namely (1) Datuk Lima Puluh with the title of Sri Bejuangsa; (2) Datuk Tanah Datar with the title of Sri Pekerma Raja; (3) Datuk Pesisir with the title Maharaja Keungsa; (4) Datuk Laksamana Raja of the Sea. In addition, there were also deputy of the sultan's assistants, such as warlords, datuk hamba raja, datuk bintara kiri, datuk bintara kanan, and datuk chamberlain. Government in the region are held by tribal chiefs called Penghulu, Orang Kaya, and Batin. Siak sultanate region consists of 12 provinces with 12 sultan government. Sultan Sharif Kasim II as the last sultan who ruled during the period of 1915-1945, handed over the sultanate to the government of the Republic of Indonesia on August 17, 1945.

Beside the two powers of Siak and Riau Johor, there were other kingdoms which grew on those places. There were kingdoms of Pelelawan and Rokan in Siak region. In Rokan river area, there were also kingdoms, such as Tembusai with its capital Dalu-Dalu, Kepenuhan with its capital Koto Tengah, Kunto Dar Es Salam with its capital Kota Lama, and Rokan with its capital Rokan IV Koto. The Rokan kingdom was well-known for siri and tarombo siri which were read during the appointment and deployment of 
the king. Tambusai Kingdom was known by their government which was led by the Sultan (Sultan Machyuddin's time), accompanied by four Great People of the Kingdom, namely (1) Datuk Sri Maharajo, (2) Datuk Paduko Tuan, (3) Datuk Tumenggung, and (4) Datuk Paduko Rajo. The four datuk were customary holders (Lutfi, 1977: 271).

In Riau-Johor kingdom, since the time of Sultan Sulaiman, with the title Sultan Abdul Jalil Riaayat Syah IV (descent of Bendahara), the power of the Sultan has been divided. Sultan was Yang Dipertuan Besar Riau, accompanied by Yam Tuan Muda of Bugis descent, namely (1) Daeng Perani; (2) Daeng Marewa; (3) Daeng Menambun; (4) Daeng Celak. Furthermore, the Sultan was only a symbol, while the daily power was exercised by Yam Tuan Muda (Suwardi, 1986:214). This situation was caused by Dutch pressure which made the Sultan as the Dutch accomplice. The territory of Sultan covering Riau Archipelago, the islands at the mouth of the Indragiri River, the Malay Peninsula, and Singapore, were later narrowed down. The Sultan (Yang Dipertuan Besar) moved to Lingga with a power area in Lingga Island, and Yang Dipertuan Muda was only in the Penyengat Island. Based on the London agreement in 1924, the power of the Yang Dipertuan Besar was further limited. Finally, the Bendahara became Sultan of Pahang and Temenggung as King of Johor. This London agreement also separated Malaya and Singapore Peninsula with Riau. Therefore, the

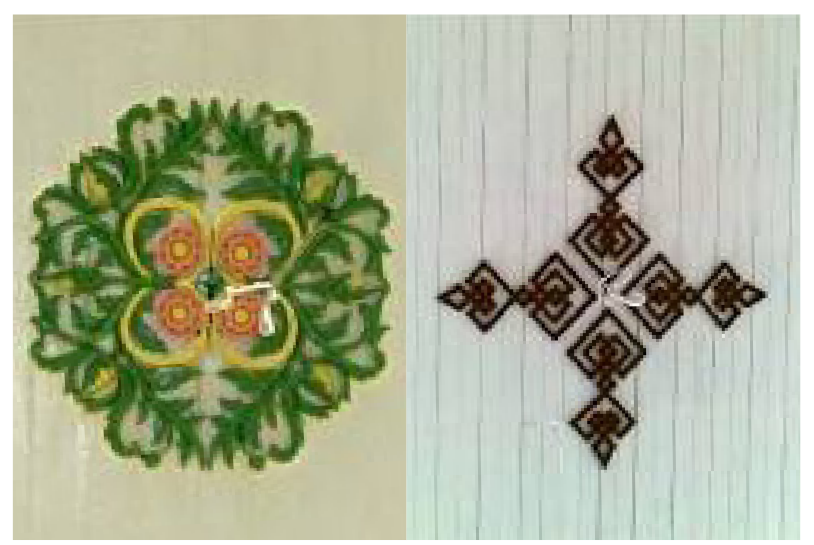

Figure 1. Pattern of four as decoration which are found in the Court Building Room (Balairung Seri) in the Palace of Siak Sri Indrapura. sultanate has been known as the Riau-Lingga Sultanate.

In Riau-Johor region grew Indragiri Kingdom (1658-1838) covering waters from the Indragiri River estuary to the border with Cerenti in Kuantan. The Indragiri kingdom was ruled by 23 kings (sultan), but since the Dutch imposed an agreement on the Indragiri Sultan (1838), the region became part of Residentie Riow en onder Hoorigheden. The area upstream of the Indragiri River called Kuantan, was an authority that came from the Kandis Kingdom. There was a famous proverb in this region "Beraja kepada mufakat dan bersultan ke Indragiri". In custom and law, it occurred custom of Datuk Perpatih nan Sebatang which meant that the king was also a religious leader (syara' or custom with the Kitabullah). There were five famous datuk, namely (1) Datuk Paduko Rajo in Lubuk Ambacang; (2) Datuk Habib in Lubuk Jambi; (3) Datuk Bisai in Taluk; (4) Datuk Sikaro in Inuman; and (5) Datuk Dano Pute domiciled in Cerenti. They were known as Gadang People who was the deputy of the king and run the government on behalf of the king in their respective territories (Lutfi, 1977:358). There was other kingdom except Kuantan Kingdom. Those kingdom was Gunung Sahilan Kingdom which was located in the Kampar Kiri area, bordering with Kuantan area.

Based on those facts, the Riau Malay Sultanate which was initially as a sultanate developed into several kingdoms which had

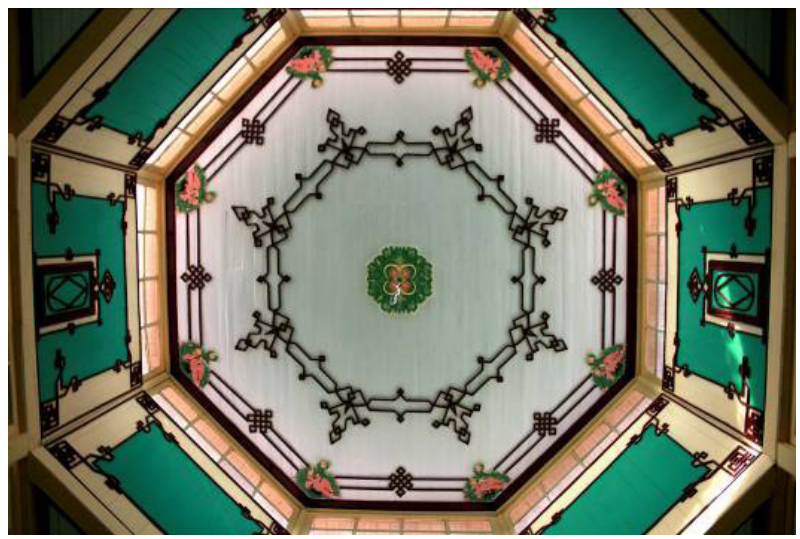

Figure 2. Pattern of eight which is found in the decoration of the Dome of the Court Building Room (Balairung Seri) in the Palace of Siak Sri Indrapura. 
their own sovereignty, but they had links with the central government of the Malay Sultanate from Bintan, Ulu Riau, Lingga, and Penyengat. However, the power of Dutch had further eliminated the sovereignty of the Malay Sultanate in Riau, especially since 1913. However, the Malay Sultanate in Riau, especially the Riau-Johor and Riau-Lingga governments, has succeeded in cultivating the Malay language into writing variety language. That was caused by intellectuals, such as Raja Ali Haji. In the life of the Malay community, the rituals, engagements, marriages, coronations of kings, and others have been regulated (Sudjiman, 1983). As the development of Islam, the customs and Malay language in the Malay Sultanate became the identity of the Malay community itself.

Penyengat Island has been successfully developed as a center of religion, language, literature, customs, and Malay art; and we can see the relics and traces of them until now (Suwardi, 1986:218). There were some historians who suspected that the Riau Archipelago and the palace of the Bintan Sultan (Penyengat Island) in the 19th century were the center of Malay culture because of the many fine historical and literary texts of these islands. The legitimacy of the Riau King might be defeated in terms of political power and wealth, but in terms of culture, they remained superior (Ham, 1986: 185).

\section{Malay Identity}

A person is regarded as a Malay when he or she fulfills the following requirements: he or she is a Muslim, speaks Malay, uses Malay customs, and fulfills certain settlement requirements (Nagata, Yudith, A.BKI-DL,130, late, p.91; and Sinar, 1986: 253). Culturally, one of Malay characteristic is occupying the concept of kingdom. The royal concept shows the king's function for the Malays, a state policy and the centralization of something to the king in the cultural identity of the old Malay. The king is a symbol of personification of community values and historical traditions. (Milner, A.C.DR, 1977. Ch.7). The concept of
Monarchy is shown in several Malay proverbs, such as "Ada raja adat berdiri, tiada raja adat mati" or "Biar mati anak, daripada mati adat".

The meaning of the kingdom was the territory of the residence or the establishment of the territory which had bandar (a crowded place or a place of business). Malay people had great respect for their king, who was descended from the dynasty and constantly (illustrius and impaccable) which was useful for legitimacy because the people and the country were easy to find. During the dynastic intact, there were no reasons to dissolve the empire. There was a set of nobat music which became the part of royal regalia, which had suprenatural power, for example by putting the Royal Jin in there. In the new king's reign, it was not valid if it was not crowned. In ancient times, when the sound of the nobat music sounded, then all activities stopped, as if the king was there.

The king was sovereign and had the magic which the ordinary people did not have. The sovereign was based on the concept of Islam which was brought to Indonesia in the 13th and 14 th centuries by the Sufi to Pasai and the Malay states. The King used the title "Sultan" or "Syah" because it was considered Zil Allah Fi'il Alam or the shadow of God above the world. It was also said that the righteous king along with the Messenger of Allah (Rasullullah), was like two gems in one ring, and if you performed your duty to him, it was all the same as doing your duty to God (Winstedt R.O. Sej. Melayu: 144). In fact, the "Tajusalatin" from Pahang interpreted Surah XI verse 30 of the Quran as "God places the king over the world as his representative". This concept may be acquired from Moslem kings in India (Nujjeb. M, 1967: 33). The Sufis added that the prince was king Insan al Kamil (the perfect man), can unite with God. Therefore, the principle of ungodliness was a great abstention to the Malays for fighting the good fortune.

In the days before the invasion of Western colonists, if a citizen felt unfairly treated by his king, they denounced by collecting his possessions and families, then boarding the boat leaving the country to move to another 
country. That activity would shame the king because prosperity and strength depended on the number of people who were faithful. Although everything was centered on the king but the king himself can not do anything without deliberating with ministers and his great men, because they had real power. The king and his great man were like fire and wood, which was a fire which was needed to burn wood. Moreover, there were no secrets to the people concerning the matters of people's welfare that was discussed openly in the Balairung Seri. The king's duty must be prioritizing the Islamic law because the king was Khalifatullah fi'il ard. The king must be fair, must give priority to his people, and must maintain their honor. Those tasks can be read in the Silat Halilintar letter from the Sultan of Aceh for the appointment of Sultan Basyaruddin from Serdang, in 1854 (Sinar, 1986: 268).

That obligation was reflected in the proverbs:

Raja memegang adatyang kanum

Adat pusaka turun temurun

Adil, arif, bijak bersusun

Pandai meneliti zaman beralun

The king holds the kanum custom

Traditional heritage generations

Fair, wise, wise-minded

Clever in analyzing at epochal times

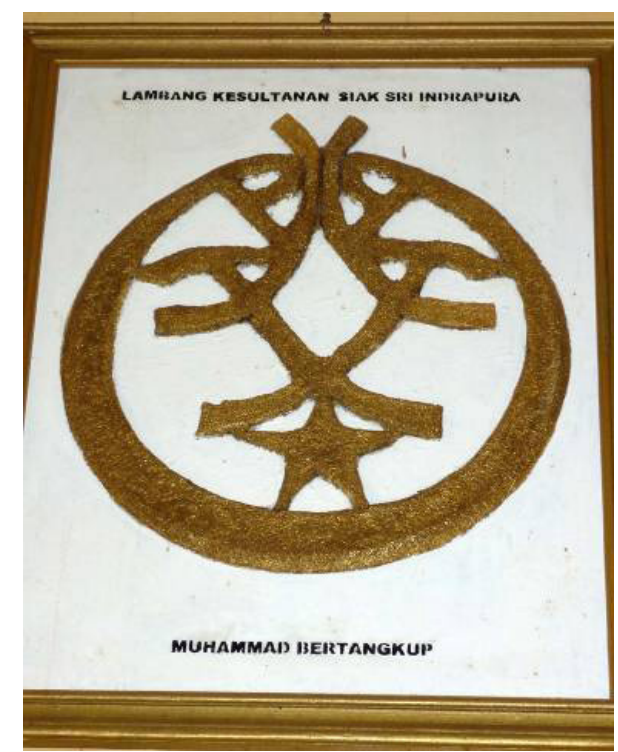

Figure 3. Symbol of Siak Sri Indrapura Sultante. Muhammad Bertangkup: Embracing fair King with the Rasulullah (Prophet), is like two gems in one ring.
In ancient times it was clear that without the institution of the Raja, the Malay world have fallen into confusion (Milner, 1977: 108). Therefore, it was fitting that the Dutch were very keen trying to destroy the institution of the Orang Besar (Great Man) (raad van Rijksgroten) in all Malay kingdoms because the Dutch knew that political power lied in the great man. Thus, it was hoped that the king would live alone as a single ruler without discussion noble and easily became a Dutch tool. Indeed, the king without a big man was totally alien in the Malay system of government, because the king's duty was actually dealing with manners and only lied a high culture (Sinar, 1986: 254).

\section{Malay Dance Pattern}

Dance is one of the richest cultural expressions yet the most difficult to analyze and interpret. It arises from the quality which becomes the main characteristics of the main society. A work of art is not responsible for its own quality and acceptance by the audience. The responsibility is also stood by the culture's circumstance of the original work. Artwork is not an object that is attached to a group of people. Dance can be understood by understanding the way and outlook of the people who created and received the dance. Aesthetic judgment of a person will always be influenced by the sharpness of appreciation, emotional atmosphere, freedom, taste, extent of appreciation, and by the idea of truth, beauty, enjoyment, and reality. In addition, there are also forces that influence a person's aesthetic judgments, such as a value system and a sense of security because of the established values of tradition in morals, religions, principles, politics, social, and even magical elements that may not realized. Aesthetics discussed philosophical theory without giving objective formulas or evidence, the goal was to discuss the value aspects of an appreciation (Ellfeldt, 1976: 136).

A dancer must animate and live the dance by living up to the content or meaning of the dance performed, and be able to communicate 

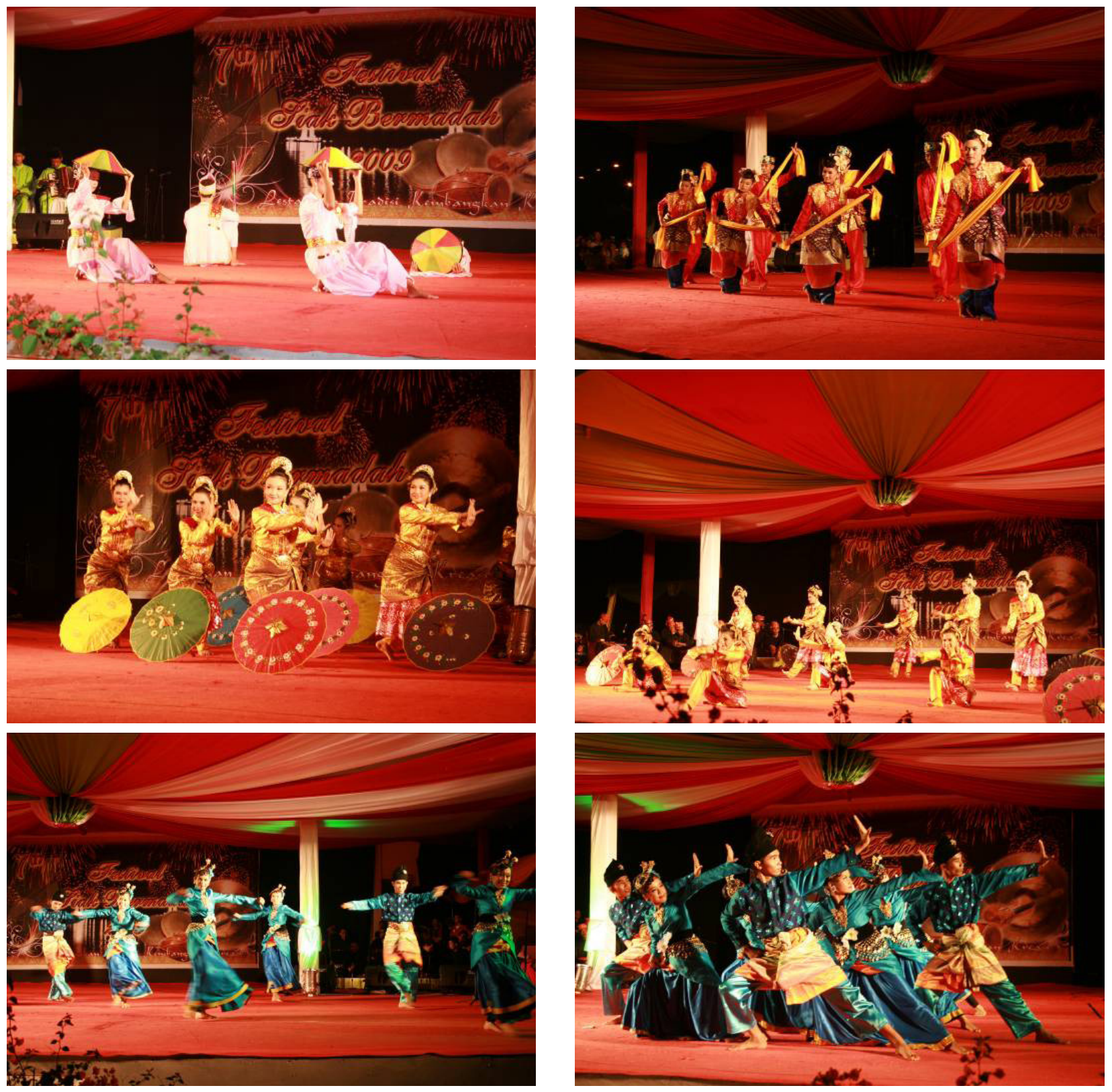

Figure 4. The features of motion which are typical Malay dances.

it with the audience. That situations show the differences between dancer and athlete. Athlete moves for the need of the muscles or to win in a game, while the dancer must be skilled to appreciate (wiroso), to feel the movements that he or she did. The ideal of Javanese dance moves is semeleh which means that the movement is done with a sense of calm and peace without any tension, in the inner atmosphere is not in a rush.

\section{Conclusion}

As discussed earlier, the position of Malay culture is very approachable to external influences. One of the greatest influences is Arab-Islam. The art of Zapin (Gambus), Khasidah, Rodat (Barodah), and Zikir Barat are influenced by Islamic culture. The influence of Siam, which passed through Kedah and Perlis, was seen in the form of Makyong, Menora and Mendu in the Tuhak Teluk Haru area of Langku and in the Kingdom of Deli Serdang.

In the Malay dance group, there are four terms which mean dance, namely (1) tandak which emphasizes on footwork; (2) igal which emphasizes the body movements; (3) liuk which emphasizes the motion of lowering the body and swinging the body and hands, like wriggling and twisting; and (4) tari (dance) 
which is marked by the movement of arms, hands, and graceful fingers. The term tari (dance) has been used to refer to Malay dance in general (Shepard, 1972: 82). Tandak dance is considered as a basic in mastering other Malay dances.

The thing that must be known in Malay dance is the rentak (rhythm), which is the certain rhythm motive (music) that underlies certain motives of motion. Rentak is the rhythm that builds the atmosphere and identity of the Malay dance. Various rentak are rentak Zapin, rentak Joged, rentak Gasal, rentak Melayu, rentak Mak Inang, rentak Nobat, divided again into three outline, they are fast rentak (Joged), moderate rentak (Inang), and slow rentak (langgam) (Monografi Daerah Riau, 124). In Malay dancers, the dancers' movements were light as surfing through the flow of water; jumping lightly like a wave of ripples breaking, bumping against small reefs. The composition developed from a slow tempo, propagated faster and reached the climax of speed at the end (Murgiyanto, 1986: 389). It is a movement that becomes the essence of Malay dance. The origin and center of Malay culture are Riau, North Sumatra, West Kalimantan, South Kalimantan, and Malaysia. In such cases, the features of motion which are typical Malay dances are seen in figure 4.

Finally, this paper is expected to provide an understanding of the Nusantara culture in a more comprehensive way, so the diversity of values that exist in Indonesian society actually becomes a reinforcement of the cultural greatness of this country. It will provide an understanding of the differences that will strengthen the sense of togetherness. Live
Indonesia Raya, build his soul, and build his body for Indonesia Raya.

\section{References}

Amanriza, Ediruslan P.E., Hasan Junus, Idrus Tintin. (ed). 1985. Pertemuan Budaya Melayu Riau. Pemerintah Daerah Tingkat I Propinsi Riau.

Budisantoso, S., Parsudi Suparlan (ed). 1985. Masyarakat Melayu Riau dan Kebudayaannya. Pekan Baru: Pemerintah Propinsi Daerah Tingkat I Riau.

Ellfeldt, Lois. 1976. Dance from Magic to Art. Dubuque, Iowa: Win. C. Brown

Geertz, Clifford. 1963. "The Integrative Revolution Primordial Sentimens and Civil Politics in the New States" dalam Old Societies and New States. New York: The Free Press of Glencoe.

Muhammad, Goenawan. 2008. "Melayu" dalam Tempo: Majalah Berita Mingguan. Edisi Nomor 23 bulan Maret 2008.

Murgiyanto, Sal. 1986. "Seni Tari Melayu: Struktur dan Refleksi Keindahan" dalam Masyarakat Melayu Riau dan Kebudayaannya. Pekanbaru: Pemerintah Propinsi Daerah Tingkat I Riau.

Ong Hok Ham. 1986. "Pemikiran tentang Sejarah Riau" dalam Masyarakat Melayu Riau dan Kebudayaannya. Pekanbaru: Pemerintah Propinsi Daerah Tingkat I Riau.

Ong Hok Ham. 2003. Wahyu yang Hilang Negeri yang Guncang. Jakarta: Pusat Data dan Analisa Tempo (PDAT).

Sabrin, Amin. Tanpa Tahun. Naskah Tarian Daerah Riau. Tanpa Penerbit. 